Article

\title{
Lead Assays with Smartphone Detection Using a Monolithic Rod with 4-(2-Pyridylazo) Resorcinol
}

\author{
Piyanat Issarangkura Na Ayutthaya ${ }^{1}$ (), Chonnipa Yeerum ${ }^{1}$, Kullapon Kesonkan ${ }^{1}$, Kanokwan Kiwfo ${ }^{2}$, \\ Kate Grudpan ${ }^{2, *}$, Norio Teshima ${ }^{3}$, Hiroya Murakami ${ }^{3}$ and Monnapat Vongboot ${ }^{1, *}$ \\ 1 Department of Chemistry, Faculty of Science, King Mongkut's University of Technology Thonburi, \\ Bangkok 10140, Thailand; piyanat.tp@gmail.com (P.I.N.A.); chonnipa.yeerum@gmail.com (C.Y.); \\ kullapon.kesonkan@gmail.com (K.K.) \\ 2 Center of Excellence for Innovation in Analytical Science and Technology and Department of Chemistry, \\ Faculty of Sciences, Chiang Mai University, Chiang Mai 50200, Thailand; k.kanokwan11@gmail.com \\ 3 Department of Applied Chemistry, Aichi Institute of Technology, 1247 Yachigusa, Yakusa-cho, \\ Toyota 470-0392, Japan; teshima@aitech.ac.jp (N.T.); hmurakami@aitech.ac.jp (H.M.) \\ * Correspondence: kgrudpan@gmail.com (K.G.); sumalee.tan@kmutt.ac.th (M.V.); Tel.: +66-5394-1917 (K.G.); \\ +66-2470-8969 (M.V.)
}

Citation: Issarangkura $\mathrm{Na}$ Ayutthaya, P.; Yeerum, C.; Kesonkan, K.; Kiwfo, K.; Grudpan, K.; Teshima,

N.; Murakami, H.; Vongboot, M. Lead Assays with Smartphone Detection

Using a Monolithic Rod with

4-(2-Pyridylazo) Resorcinol. Molecules 2021, 26, 5720

https://doi.org/10.3390/

molecules 26185720

Academic Editors: Wenyue Gao, Jingying Zhai and Marek Trojanowicz

Received: 18 August 2021

Accepted: 18 September 2021

Published: 21 September 2021

Publisher's Note: MDPI stays neutral with regard to jurisdictional claims in published maps and institutional affiliations.

Copyright: (c) 2021 by the authors. Licensee MDPI, Basel, Switzerland. This article is an open access article distributed under the terms and conditions of the Creative Commons Attribution (CC BY) license (https:/ / creativecommons.org/licenses/by/ $4.0 /)$.
Abstract: A monolithic rod of polyurethane foam-[4-(2-pyridylazo) resorcinol] (PUF-PAR) as a simple chemical sensor for lead assays with smartphone detection and image processing was developed. With readily available simple apparatus such as a plastic cup and a stirrer rod, the monolithic PUF rod was synthesized in a glass tube. The monolithic PUF-PAR rod could be directly loaded by standard/sample solution without sample preparation. A one-shot image in G/B value from a profile plot in ImageJ for a sample with triplicate results via a single standard calibration approach was obtained. A linear single standard calibration was: $[\mathrm{G} / \mathrm{B}$ value $]=-0.038\left[\mu \mathrm{g} \mathrm{Pb}{ }^{2+}\right]+2.827, \mathrm{R}^{2}=0.95$ for 10-30 $\mu \mathrm{g} \mathrm{Pb}{ }^{2+}$ with a limit of quantitation (LOQ) of $33 \mu \mathrm{g} \mathrm{L}^{-1}$. The precision was lower than $15 \%$ RSD. The proposed method was tested by an assay for $\mathrm{Pb}^{2+}$ contents in drinking water samples from Bangkok. The results obtained by the proposed method agree with those of ICP-OES and with $100-120 \%$ recovery, demonstrating that the method is useful for screening on-site water monitoring.

Keywords: monolithic polyurethane foam-[4-(2-pyridylazo) resorcinol]; chemical sensor; lead; smartphone; on-site screening; water monitoring

\section{Introduction}

Lead is a substance of concern due to its toxicity. According to Thailand's guidelines for health effects, a maximum of $50 \mu \mathrm{g} \mathrm{L}{ }^{-1}$ of lead is allowed in drinking water [1]. The standard methods for water analysis usually employ colorimetry (using dithizone reagent), atomic absorption spectroscopy (AAS) with flame and non-flame, inductively coupled plasma optical emission spectrometry/mass spectrometry (ICP-OES/MS), and anodic stripping voltammetry (ASV) [2]. The development of lead determination has been of interest for various kinds of applications, including water monitoring. Even in recent decades, there have been a number of reports devoted to lead monitoring, including the use of nanoparticles [3-6] and smartphones [7-11], although various screen-printed electrodes have been used for the electrochemical analysis of lead [12-14], with the aims of improved sensitivity and more convenient procedures.

4-(2-pyridylazo) resorcinol (PAR) has been a color reagent of interest for lead determination since the 1960s [15], due to its good solubility in water, rapid color formation, reasonable sensitivity, and high stability for lead complexes [16]. PAR, which could be viable in laboratories, has made the colorimetric determination of lead a popular implementation, with simple operation. Pretreatment may be associated with the colorimetric determination of lead using PAR. Some sorbents such as AV-17 [17-19], polyurethane foam 
(PUF) [20], Amberlite XAD-1180 [21], Amberlite XAD-7 [22], modified silica [23], imprinted polymer nanoparticles [24], modified nano-alumina [6], nanomagnetic materials [3,5], TrisKem Pb resin [25], NOBIAS chelate PA-1 [26], Amberlite IR-120 [27], PB-resin [28], and nonwoven polypropylene [29] have been employed. Some of those were used to sorb lead with elution, for the next step of forming color with PAR for a colorimetric assay [22,25-28]. In some previous works, lead that formed anionic complexes before being sorbed on AV-17 could then form a color complex when treated with a PAR solution [17-19]. The silica was treated with mixed ligands for the sorption of lead before forming a color product with PAR [23]. In both the latter cases, detection with diffuse reflectance spectrometry was employed.

Polyurethane foam (PUF) has gained interest for use as a sorbent for lead [20,30-47]. Many previous works have been devoted to pretreatment for the determination of lead by atomic absorption spectrometry. Only one of them was applied using PAR [20]; PUF, as purchased, was made into a powder and packed into a column, then loaded with PAR in a flow injection system. The eluted lead from the column was then allowed to flow into AAS for lead determination.

Recently, our research group introduced PUF as a monolithic rod with the single standard calibration approach for anionic surfactant assays, employing methylene blue reagent [48] and a PUF-alginate monolithic rod for lead determination using flow injectionflame atomic absorption spectrometry [49].

It would, therefore, be of interest to make use of PUF loading with PAR as a monolithic column to sorb lead, producing a color product $\left(\mathrm{Pb}^{2+}-\mathrm{PAR}\right.$ sorbed on PUF) with the use of smartphone detection for various expected benefits, such as simplicity in monolithic PUF-PAR rod fabrication for a ready-to-use chemical sensor, according to the IUPAC definition of a sensor [50] with a one-shot image, and the advantage of the single standard calibration approach without sample preparation for on-site water monitoring.

\section{Results}

\subsection{The Monolithic PUF-PAR Rod}

A monolithic PUF rod (obtained from the synthesis) of a cylindrical shape, $2 \mathrm{~cm}$ in height, with good porosity characteristics, was instantly packed into the glass rod to create a mold during the synthesis step. The color of the obtained monolithic PUF rod was white (see Figure 1a). After loading with a PAR solution, and being left to dry, the PUF immobilized with PAR resulted in a yellow monolithic PUF-PAR rod, as depicted in Figure $1 b$. When passing a $\mathrm{Pb}^{2+}$ solution, red coloration appeared on the monolithic PUF-PAR rod (see Figure 1c). The higher the concentration of $\mathrm{Pb}^{2+}$, the more intense the color observed. In one batch of fabrication of the monolithic PUF-PAR rod, i.e., synthesizing the backbone monolithic PUF rod in a glass rod as a mold, and immobilizing PAR, 40 monolithic rods could be obtained, and were ready to use as working monolithic PUF-PAR rods for lead assays (cf. A in Figure S1). The working monolithic PUF-PAR rod could be kept in a desiccator for further use for at least a week.

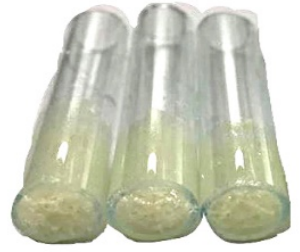

(a)

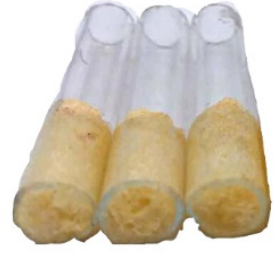

(b)

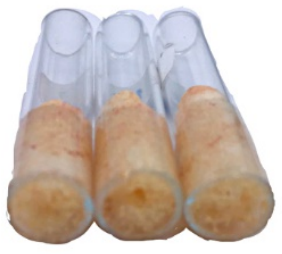

(c)

Figure 1. Monolithic rods of: (a) PUF; (b) PUF-PAR; and (c) PUF-PAR after passing a $\mathrm{Pb}^{2+}$ solution.

\subsection{The Proposed Water Monitoring Procedure}

An analyte solution (standard/sample) with the desired volume was loaded through a monolithic PUF-PAR rod and left to dry. A set of nine rods (six rods for $\mathrm{Pb}^{2+}$ standards, and 
three rods of a sample for triplicate results) was employed for each sample (see Figure 2). The one-shot image was obtained using a smartphone under the light control box. Image processing was carried out using ImageJ for the ratio of the $G / B$ value, where the $G$ value and $B$ value refer to the color intensities of the color mode: red (R), green $(\mathrm{G})$, and blue (B).

It is noted that the above analysis procedure is composed of two steps: detection (loading and photographing) and evaluation (cf. B and C in Figure S1). After loading, it was left to dry (for approximately two hours) before photographing. During the drying period, operation of the other sites could be performed in parallel. The photographing would take less than one minute, and then it would take less than five minutes for evaluation, including image processing, to obtain the triplicate analysis results. This is still useful for the on-site monitoring approach.

Loaded $\mathrm{Pb}^{2+}$ (in microgram) on a monolithic PUF-PAR rod could be computed by: $\mathrm{Pb}^{2+}$ microgram $=\mathrm{C}_{\mathrm{Pb}}{ }^{2+} \times \mathrm{FR}_{\text {analyte solution }} \times \mathrm{LT}$, where $\mathrm{C}_{\mathrm{Pb}}{ }^{2+}$ is the $\mathrm{Pb}^{2+}$ concentration $\left(\mu \mathrm{g} \mathrm{mL}^{-1}\right)$ in the solution, $\mathrm{FR}_{\text {analyte solution }}$ is the flow rate of analyte $\left(\mathrm{mL} \mathrm{min}{ }^{-1}\right)$, and LT is the loading time (min). A linear calibration graph can be established by a plot of the $\mathrm{Pb}^{2+}$ microgram against the $\mathrm{G} / \mathrm{B}$ value. However, the equation can be reduced to

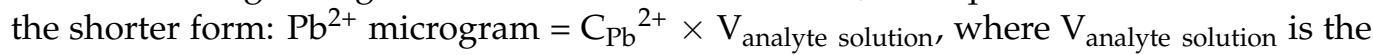
loading volume.

A linear calibration graph, using a single standard calibration approach (see detail in Section 3.3), was obtained by a plot of the $\mathrm{Pb}^{2+}$ microgram against the $\mathrm{G} / \mathrm{B}$ value (see Figure 2).

The calibration equation was: $\mathrm{G} / \mathrm{B}$ value $=-0.038\left[\mu \mathrm{g} \mathrm{Pb}{ }^{2+}\right]+2.827\left(\mathrm{R}^{2}=0.95\right)$ for the linear range of $10-30 \mu \mathrm{g} \mathrm{Pb}^{2+}$. The precision of the proposed method was less than $15 \%$ RSD.

It can be observed from Table 1 that using a solution of $0.4 \mu \mathrm{g} \mathrm{mL}{ }^{-1} \mathrm{~Pb}^{2+}$ for I-G positions, with different loading volumes, resulted in different $\mu \mathrm{g}$ from the single standard calibration but yielded the same concentration values. In this way, triplicate results could be obtained even when using different loading volumes. This offers a method through which to verify the obtained results.

The developed procedure was tested for real application in assays of $\mathrm{Pb}^{2+}$ in drinking water samples from coin-operated drinking water vending machines in various districts of Bangkok (see Figure 3), Thailand, including Dindaeng (S1), Bangkapi (S2), Huai Khwang (S3), and Thungkru (S4). The $\mathrm{pH}$ values of the drinking water samples were found to be 7 \pm 0.5 , so the samples were directly loaded to the monolithic PUF-PAR rod without any sample pretreatment. The results are summarized in Table 2.

The results obtained by the proposed method agree with those obtained by the ICPOES method. When spiking each sample with $50 \mathrm{~Pb}^{2+} \operatorname{std}\left(\mu \mathrm{g} \mathrm{L}^{-1}\right)$, which is the maximum acceptable concentration of lead in drinking water, the results obtained by the proposed procedure are $50 \pm 10 \mu \mathrm{g} \mathrm{L}^{-1}$, indicating that the sensitivity of the proposed procedure is appropriate for screening water in accordance with Thailand's guidelines for the maximum allowance of lead [1].

It was found that the observed values were less than the theoretical values (2.92 at $95 \%$ confidence level), indicating no significant difference. The aim of this work is to report the development of simple procedures for lead assays employed in water monitoring. However, we are aware that the number of samples needs to be increased to verify the utility of the method. Further work regarding water monitoring on a larger scale is planned. 
Table 1. Assay using the proposed procedure for one-shot image of a sample with triplicate results via a single standard calibration approach.

\begin{tabular}{|c|c|c|c|c|c|c|c|c|}
\hline \multirow{2}{*}{$\begin{array}{l}\text { Position (in } \\
\text { Figure 2) }\end{array}$} & \multicolumn{3}{|c|}{ Loading $\mathrm{Pb}^{2+}$} & \multicolumn{2}{|c|}{ Intensity } & \multirow[b]{2}{*}{ G/B value ${ }^{c}$} & \multicolumn{2}{|c|}{$\mathrm{Pb}^{2+}$ found } \\
\hline & $\mu \mathrm{g}$ & $\mu \mathrm{g} \mathrm{mL^{-1 }}$ & $\begin{array}{c}\text { Loading } \\
\text { volume }(\mathrm{mL})\end{array}$ & G value & B value & & $\mu g^{a}$ & $\begin{array}{c}\text { Concentration } \\
\left(\mu \mathrm{g} \mathrm{mL} \mathrm{L}^{-1}\right)\end{array}$ \\
\hline A & 10 & 0.2 & 50 & 200 & 80 & 2.5 & - & - \\
\hline $\mathrm{D}$ & 10 & 0.5 & 20 & 200 & 80 & 2.5 & - & - \\
\hline B & 20 & 0.1 & 200 & 200 & 100 & 2.0 & - & - \\
\hline $\mathrm{C}$ & 20 & 0.1 & 200 & 200 & 90 & 2.2 & - & - \\
\hline $\mathrm{E}$ & 30 & 0.3 & 100 & 170 & 95 & 1.8 & - & - \\
\hline $\mathrm{F}$ & 30 & 0.5 & 60 & 170 & 95 & 1.8 & - & - \\
\hline I & - & - & 40 & 200 & 90 & 2.2 & 18 & $0.4^{b}$ \\
\hline $\mathrm{H}$ & - & - & 50 & 195 & 105 & 1.9 & 27 & $0.5^{b}$ \\
\hline G & - & - & 70 & 200 & 115 & 1.7 & 32 & $0.4^{b}$ \\
\hline
\end{tabular}

${ }^{\mathrm{a}} \mu \mathrm{g}$ from calibration; ${ }^{\mathrm{b}}$ see text; ${ }^{\mathrm{c}}$ the ratio of the G/B value, where the $\mathrm{G}$ (green) value and $\mathrm{B}$ (blue) value refer to the color intensities of the color mode.

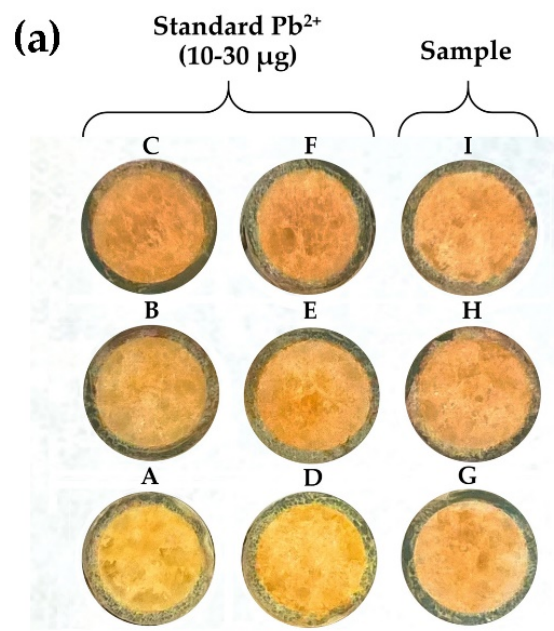

(b)
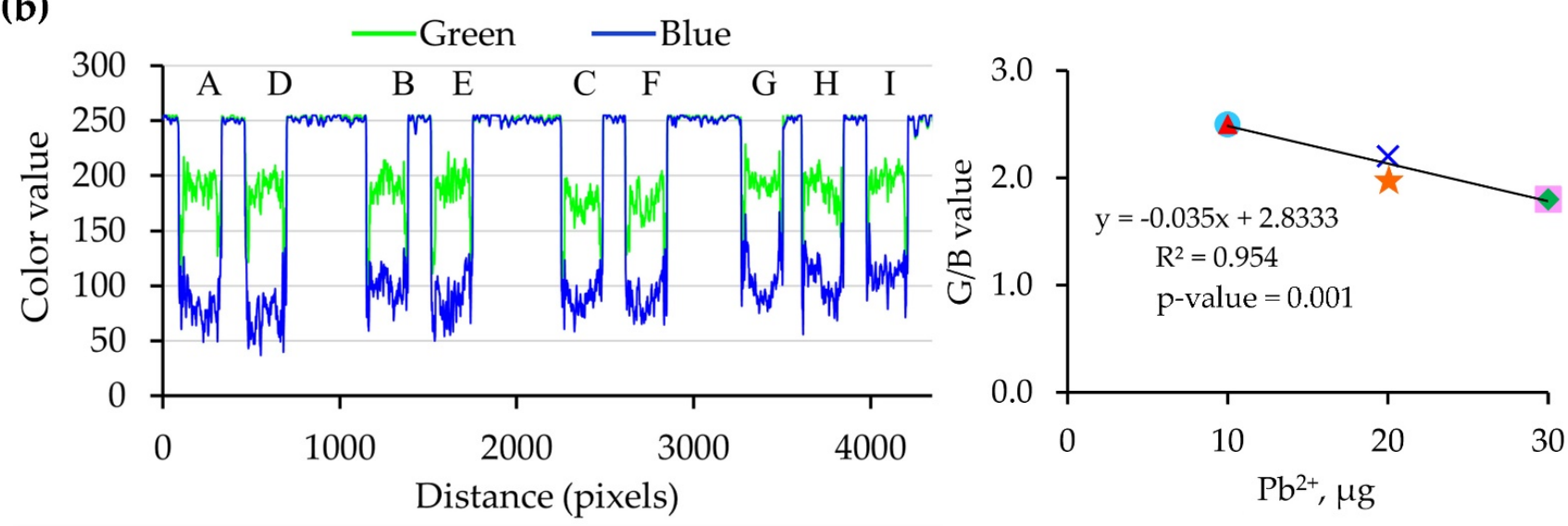

Figure 2. Assay using the proposed procedure for one-shot image of a sample with triplicate results via a single standard calibration approach: (a) one-shot photo taken of the nine rods ( $\mathrm{A}-\mathrm{F}$ due to the $\mathrm{Pb}^{2+}$ standards, $\mathrm{G}-\mathrm{I}$ due to a sample with different loading volumes); (b) profile of $\mathrm{G}$ and B values with calibration graph (see Table 1): A $(\boldsymbol{\Delta}), \mathrm{B}(\star), \mathrm{C}(\bullet), \mathrm{D}(\bullet), \mathrm{E}$ $(\times), \mathrm{F}(\square)$. 


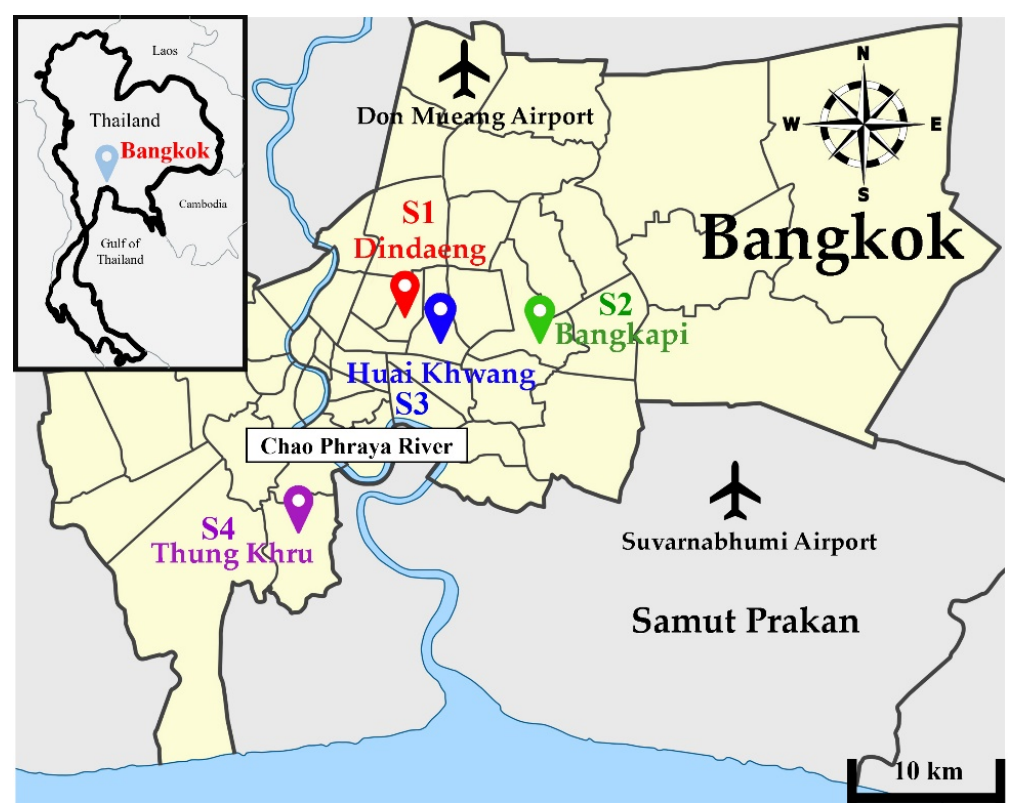

Figure 3. Sampling areas in Bangkok, Thailand for lead assays of drinking water samples.

Table 2. Assay of lead contents in drinking water samples from different districts in Bangkok.

\begin{tabular}{|c|c|c|c|c|c|c|c|}
\hline \multirow{3}{*}{ Sample } & \multirow{3}{*}{ Monitoring site ${ }^{a}$} & \multirow{3}{*}{$\begin{array}{l}\text { Added } \mathrm{Pb}^{2+} \text { std } \\
\qquad\left(\mu \mathrm{g} \mathrm{L}^{-1}\right)\end{array}$} & \multicolumn{4}{|c|}{ Found $\mathrm{Pb}^{2+}$} & \multirow[t]{3}{*}{$t_{\text {observed }}{ }^{d}$} \\
\hline & & & \multicolumn{3}{|c|}{ Proposed method $(n=3)$} & \multirow{2}{*}{$\begin{array}{c}\text { ICP-OES }(n=3) \\
\mu \mathrm{g} \mathrm{L}^{-1}\end{array}$} & \\
\hline & & & $\mu g^{c}$ & $\mu \mathrm{g} \mathrm{L}^{-1}$ & \% Recovery & & \\
\hline S1 (Dindaeng) & $\begin{array}{c}13^{\circ} 46^{\prime} 12.80644^{\prime \prime} \mathrm{N} \\
100^{\circ} 33^{\prime} 31.986^{\prime \prime} \mathrm{E}\end{array}$ & $\overline{50^{b}}$ & $\begin{array}{c}\text { ND } \\
18 \pm 2\end{array}$ & $60 \pm 7$ & - & $\begin{array}{c}\text { ND } \\
49 \pm 0.4\end{array}$ & 2.70 \\
\hline S2 (Bangkapi) & $\begin{array}{l}13^{\circ} 46^{\prime} 7.2408^{\prime \prime} \mathrm{N}, \\
100^{\circ} 38^{\prime} 30.03^{\prime \prime} \mathrm{E}\end{array}$ & 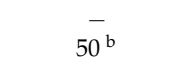 & $\begin{array}{c}\text { ND } \\
18 \pm 5\end{array}$ & $60 \overline{-}$ & $\frac{-}{120}$ & $\begin{array}{c}\text { ND } \\
48 \pm 0.4\end{array}$ & 1.22 \\
\hline $\begin{array}{l}\text { S3 (Huai } \\
\text { Khwang) }\end{array}$ & $\begin{array}{c}13^{\circ} 48^{\prime} 1.1916^{\prime \prime} \mathrm{N}, \\
100^{\circ} 35^{\prime} 1.41^{\prime \prime} \mathrm{E}\end{array}$ & $\overline{50^{b}}$ & $\begin{array}{c}\text { ND } \\
15 \pm 4\end{array}$ & $50 \pm 13$ & $\overline{100}$ & $\begin{array}{c}\text { ND } \\
44 \pm 0.8\end{array}$ & 0.79 \\
\hline S4 (Thungkru) & $\begin{array}{l}13^{\circ} 38^{\prime} 58.182^{\prime \prime} \mathrm{N} \\
100^{\circ} 29^{\prime} 46.9896^{\prime \prime} \mathrm{E}\end{array}$ & $-\frac{-}{50^{b}}$ & $\begin{array}{c}\text { ND } \\
18 \pm 3\end{array}$ & $\begin{array}{c}- \\
60 \pm 10\end{array}$ & - & $\begin{array}{c}\text { ND } \\
48 \pm 0.4\end{array}$ & 2.07 \\
\hline
\end{tabular}

${ }^{\mathrm{a}}$ monitoring sites with latitude and longitude; ${ }^{\mathrm{b}}$ a total of $50 \mathrm{~Pb}^{2+} \mathrm{std}\left(\mu \mathrm{g} \mathrm{L}^{-1}\right)$ was purposely added following the maximum acceptable concentration of lead in drinking water [1]; ${ }^{c} \mu$ g evaluated from the calibration; $\mathrm{ND}=$ not detectable; ${ }^{\mathrm{d}} \mathrm{t}_{\text {observed }}$ values were less than theoretical values ( 2.92 at $95 \%$ confidence level), indicating no significant difference.

\section{Discussion}

\subsection{Properties of the Monolithic PUF-PAR Rod}

Unlike that mentioned earlier (that PUF used in previous works was commercially available), in this work, the monolithic PUF rod was synthesized by modifying the work of $[48,49]$ and by utilizing readily available simple apparatus such as a plastic cup and a stirrer rod. Methylene diphenyl diisocyanate (MDI) was mixed for a few minutes with polyol and additives (water and silicone oil). By plugging the glass rods into the mixture, polymerization reactions took place within five minutes in the glass rods, which served as molds within which to form the monolithic rods. PAR was immobilized onto the PUF monolithic rods by loading with PAR solution for one hour and being left to dry overnight.

Employing the 2:1 ratio of diisocyanate groups from MDI and polyol groups could properly generate rigid PUF in the rod due to the potential rigidity of the aromatic parts provided by MDI. The white foam could be achieved from this ratio, as there is no profusion of brown color from MDI, resulting in no brown color interfering in the colorimetric detection step. PUF is shrunken and cohesive when the ratio of the polyol is higher than that of MDI, on account of the excess softened part for forming the monolithic PUF rod. Water, as a chemical blowing agent, serves to enlarge the porous cell and enhance the 
height of the foam by the generation of $\mathrm{CO}_{2}$ during the polymerization processes. Silicone oil, as a surfactant, serves to control the size of the porous cell, and increase the numbers of open cells. Consequently, this enhances the porosity characteristics (higher number of pores, higher surface area, and well-controlled porousness), resulting in the smooth flow of the solution and the whiteness of the obtained PUF. The obtained monolithic PUF rod possesses these properties, while the PUF in powder lacks them.

The resulting characteristics of the obtained PUF monolithic rods offer advantages over the PUF in powder form that was used in previous works [20,30,31,34-36,38,40,42,45,51].

The chemical structure of PUF consists of two parts: the diisocyanate group (-NHCO-) and the polyol groups (-C-O-C-), which are depicted in Figure 4a, relating to Figure 1a. It could be that the monolithic PUF performs as a weak positive charge [52] due to the inducing of aromatic rings and carbonyl groups, as shown in Figure $4 \mathrm{~b}$ in connection to Figure $1 \mathrm{~b}$. At pH 7, PAR as the negative charge (denoted as $\mathrm{HPAR}^{-}$) may sorb on an amino group of PUF [53]. Typically, toluene diisocyanate (TDI), well known for its isocyanate groups, is used in commercialized PUFs. Using the diisocyanate group from MDI instead of TDI can possibly support the amino group of PUF to be the more positive charge, because MDI includes two aromatic rings, whereas TDI has only one. For this reason, the amino group of the urethane bond may enhance the transference of electrons to the aromatic ring because of its electron-donating character. Moreover, the highly positive charge of the amino group predominant in commercialized PUFs and the sorption of PAR could be strong. After passing the $\mathrm{Pb}^{2+}$ solution, it would sorb on the monolithic PUF-PAR rod as $\mathrm{Pb}^{2+}$-PAR complexes. $\mathrm{Pb}^{2+}$ may bind with the pyridine nitrogen atom, azo-nitrogen atom, and o-hydroxyl group of PAR (see Figure 4c, associated with Figure 1c) [53].

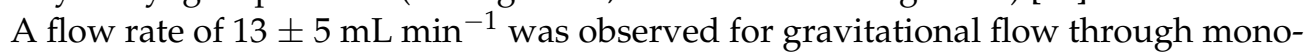
lithic PUF-PAR rods $(n=90)$, so the procedure was designed without using a pump. A sample can be directly loaded into the monolithic PUF-PAR rod without any extra sample preparation.

\subsection{Parameters Affecting the Color Development: PAR Concentration and $p H$}

In the preliminary investigation, color measurement, PUF-PAR in powder form was studied by adding the PUF-PAR powder $(0.25 \mathrm{~g})$ to $\mathrm{Pb}^{2+}$ solutions $\left(0.1-100 \mu \mathrm{g} \mathrm{mL}{ }^{-1}\right)$. The mixture was shaken by a horizontal shaker at $110 \mathrm{rpm}$ for two hours. The powder was filtered out and dried before taking a photo with a smartphone camera under the light control box. It was observed that the color of the PUF-PAR powder changed from yellow to red in accordance with the PAR and the $\mathrm{Pb}^{2+}-\mathrm{PAR}$ complex formation. The image characteristics were studied. It was found that the R (red), G (green), and B (blue) values, which are the color properties, did not have any direct correlation with the $\mathrm{Pb}^{2+}$ concentration. The CMYK (cyan, magenta, yellow, key) mode provided no direct correlation either. It was found that G/B (green divided by blue) or R/B (red divided by blue) values resulted in a linear relationship with the $\mathrm{Pb}^{2+}$ concentration; the ratio of the $\mathrm{G} / \mathrm{B}$ value was chosen for further study, as the G/B value resulted in higher sensitivity.

\subsubsection{PAR Concentrations}

Instead of a column packed with PUF-PAR powder, a monolithic PUF-PAR rod was used, as it offers smooth passage through solution. The concentration of PAR was an important parameter for the color development of $\mathrm{Pb}^{2+}-\mathrm{PAR}$ complexes in which an excess amount of PAR was required. The effect of PAR concentration was studied for PAR concentrations at $0.01,0.05$, and $0.1 \% w / v$. The concentrations of $\mathrm{Pb}^{2+}$ varying from 0.5 to $5 \mu \mathrm{g} \mathrm{mL}{ }^{-1}$ were percolated into the monolithic PUF-PAR rod with a certain volume. No significant difference was observed for coloration of $\mathrm{Pb}^{2+}-\mathrm{PAR}$ complexes via the G/B value of 0.05 and $0.1 \% w / v$ PAR, while $0.01 \% w / v$ PAR produced lower signals of $\mathrm{G} / \mathrm{B}$ value, indicating an insufficient amount of the reagent for complex formation. The concentration of $0.05 \% w / v$ PAR was chosen for further study. 


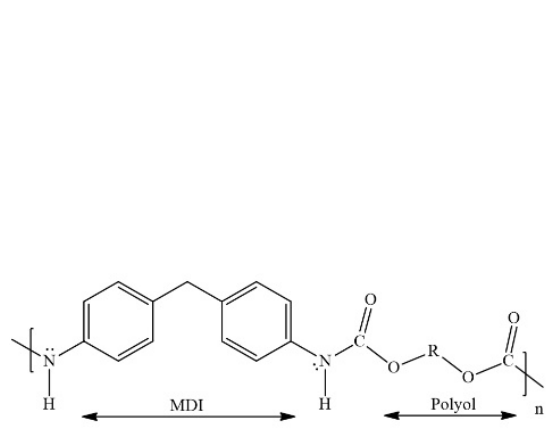

(a)

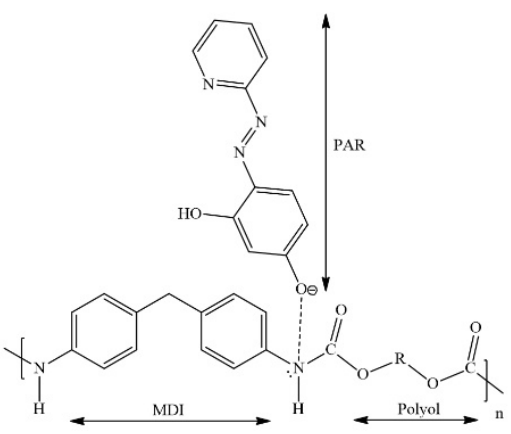

(b)

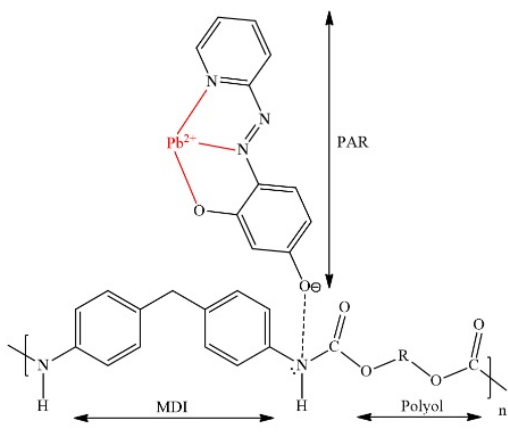

(c)

Figure 4. Proposed chemical structures of: (a) PUF; (b) PUF-PAR; and (c) PUF-PAR after passing a $\mathrm{Pb}^{2+}$ solution.

\subsubsection{Effect of $\mathrm{pH}$}

PAR consists of four diverse forms that depend on the $\mathrm{pH}$ of the solution, and persist with different charges and colors, namely $\mathrm{H}_{3} \mathrm{~L}^{+}$(yellow), $\mathrm{H}_{2} \mathrm{~L}$ (yellow-orange), $\mathrm{HL}^{-}$(orange), and $\mathrm{L}^{2-}$ (red) [53]. The wavelength of the maximum absorption of the red $\mathrm{Pb}^{2+}-\mathrm{PAR}$ complex is $520 \mathrm{~nm}$ at various $\mathrm{pH}$, ranging from $\mathrm{pH} 4$ to 12 [15]. As the $\mathrm{Pb}^{2+}-\mathrm{PAR}$ complexes were formed on the PUF-PAR surface, the $\mathrm{pH}$ of the loading solution affected the form of PAR on the surface. Therefore, the optimal $\mathrm{pH}$ of the loading solution was then investigated. Each of the solutions, containing $20 \mu \mathrm{g} \mathrm{\textrm {Pb } ^ { 2 + }}$ with $\mathrm{pH}$ varying from 1 to 10 , was percolated to the monolithic PUF-PAR rod. The effect of $\mathrm{pH}$ on the G/B value, and thus on the amount of the $\mathrm{Pb}^{2+}-\mathrm{PAR}$ complexes, is represented in Figure $5 . \mathrm{Pb}^{2+}-\mathrm{PAR}$ complexes rarely formed at $\mathrm{pH} 1$ and partially formed at $\mathrm{pH} 2-4$, because hydrogen ions competitively protonate the nitrogen

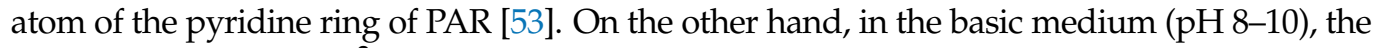
complexation of the $\mathrm{Pb}^{2+}-\mathrm{PAR}$ complex was decreased because of the plausible interaction between $\mathrm{Pb}^{2+}$ and hydroxide ions such as $\mathrm{Pb}(\mathrm{OH})_{2}$ at $\mathrm{pH} 10$, so the $\mathrm{Pb}^{2+}-\mathrm{PAR}$ complexes could scarcely occur [54]. Obviously, $\mathrm{pH} 7$ provided the maximum G/B value because of the existent forms of $\mathrm{H}_{2} \mathrm{~L}$ and $\mathrm{HL}^{-}$of PAR. The occurrence of $\mathrm{Pb}^{2+}-\mathrm{PAR}$ complexes on PUF at $\mathrm{pH}$ 7 was found to be appropriate, which agreed with a previous report [20]. Moreover, the weak positive charge from the amino group dramatically encouraged the sorption of PAR on PUF.

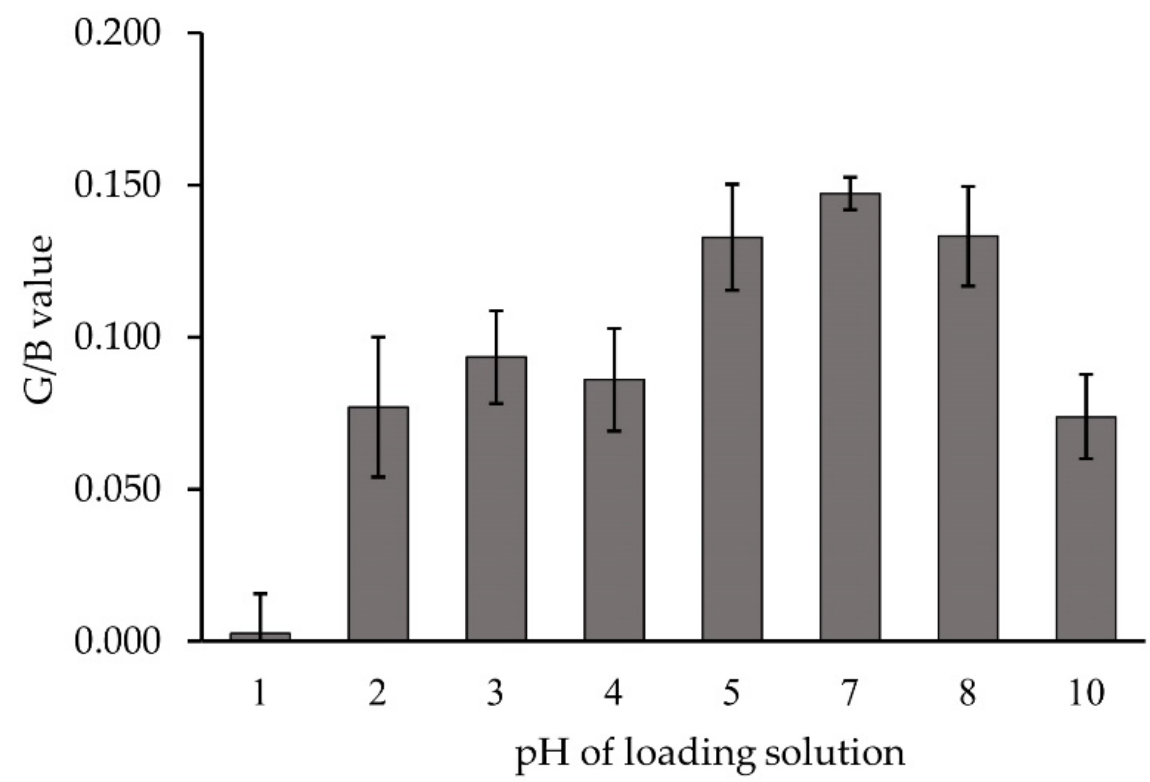

Figure 5. Effect due to $\mathrm{pH}$ of loading solution (see text in Table 1). 


\subsection{Single Standard Calibration}

In preliminary study, it was observed that the G/B value was directly proportional to the loading volume of a $\mathrm{Pb}^{2+}$ solution of a given concentration. This indicated that the single standard method could possibly be applied, as described earlier (in Section 2.2), when calculating the expected amount of $\mathrm{Pb}^{2+}$ (in microgram) of a solution percolating through a monolithic PUF-PAR rod. Various loading volumes from 5 to $100 \mathrm{~mL}$ of $\mathrm{Pb}^{2+}$ solutions at concentrations of 0.1 to $2 \mu \mathrm{g} \mathrm{mL}{ }^{-1}$ were studied. The range of $\mathrm{Pb}^{2+}$ amounts at $10-40 \mu \mathrm{g}$ was obtained using different volumes and concentrations of $\mathrm{Pb}^{2+}$ (Table 3). In addition, though the same amount of $\mathrm{Pb}^{2+}$ was obtained from diverse conditions, the same value of the resulting $\mathrm{G} / \mathrm{B}$ signals was observed. The $\mathrm{G} / \mathrm{B}$ value increased with the amount of $\mathrm{Pb}^{2+}$. However, at the higher amount of $\mathrm{Pb}^{2+}(30-40 \mu \mathrm{g})$, the G/B value became constant. This is due to the limitations of the PUF-PAR surface area and the amount of PAR.

Table 3. Loading $\mathrm{Pb}^{2+}$ solutions of different concentrations and volumes for single standard calibration $(n=3)$.

\begin{tabular}{|c|c|c|c|}
\hline $\begin{array}{c}\text { Amount of } \mathrm{Pb}^{2+} \\
(\mu \mathrm{g})\end{array}$ & $\begin{array}{l}\text { Concentration of } \\
\qquad \mathrm{Pb}^{2+} \\
\left(\mu \mathrm{g} \mathrm{mL}^{-1}\right)\end{array}$ & $\begin{array}{l}\text { Loading Volume } \\
\qquad(\mathrm{mL})\end{array}$ & $\mathrm{G} / \mathrm{B}^{\mathrm{a}} \pm \mathrm{SD}^{\mathrm{b}}$ \\
\hline 10 & 0.1 & 100 & $2.5 \pm 0.3$ \\
\hline 10 & 0.2 & 50 & $2.5 \pm 0.3$ \\
\hline 10 & 2.0 & 5 & $2.6 \pm 0.2$ \\
\hline 20 & 0.2 & 100 & $2.1 \pm 0.2$ \\
\hline 20 & 0.5 & 40 & $2.1 \pm 0.3$ \\
\hline 20 & 2.0 & 10 & $2.0 \pm 0.1$ \\
\hline 30 & 0.3 & 100 & $1.7 \pm 0.1$ \\
\hline 30 & 0.5 & 60 & $1.8 \pm 0.1$ \\
\hline 30 & 2.0 & 15 & $1.8 \pm 0.1$ \\
\hline 40 & 0.5 & 80 & $1.6 \pm 0.2$ \\
\hline 40 & 2.0 & 20 & $1.6 \pm 0.1$ \\
\hline
\end{tabular}

$\bar{a}$ The ratio of $\mathrm{G} / \mathrm{B}$ value, where the $\mathrm{G}$ (green) value and $\mathrm{B}$ (blue) value refer to the color intensities of the color mode. ${ }^{b} \pm S D$ is the standard deviation of triplicate measurements of the $G / B$ values.

The results of the studies confirm the possibility of employing the single standard calibration approach.

The lowest amount of $\mathrm{Pb}^{2+}$ in the linear calibration (Section 2.2) was $10 \mu \mathrm{g} \mathrm{Pb}^{2+}$. Considering a loading volume of $300 \mathrm{~mL}$ for $10 \mu \mathrm{g} \mathrm{Pb}{ }^{2+}$, which was the last point of the calibration, would result in $33 \mu \mathrm{g} \mathrm{L}{ }^{-1} \mathrm{~Pb}^{2+}$, which indicated the limit of quantitation (LOQ). The LOQ of the proposed procedure is lower than Thailand's guidelines for the maximum allowance of lead, being $50 \mu \mathrm{g} \mathrm{L}^{-1} \mathrm{~Pb}^{2+}$.

It should be noted that, for an additional advantage when using the single standard approach for a given set of conditions (constant flow rate), if loading a sample solution with a given loading volume produced a G/B value lower than the lowest point of the linear calibration, the sample solution could be reloaded with a more appropriate loading volume to produce a G/B value within the linear range. Similarly, if loading a sample solution resulted in a higher $G / B$ value, a lower reloading volume would provide a $G / B$ value within the linear range. It is worth mentioning that the previous reports [9,12-14], employing sensors with electrochemical analysis of 3-17 min duration, provided reported LODs of 1-4.4 $\mu \mathrm{g} \mathrm{L}^{-1}$ being converted to LOQs of 3-15 $\mu \mathrm{g} \mathrm{L}^{-1}$, by calculating LOQ $=3.3 \mathrm{LOD}$. The sensors with nanomaterials $[8,10,11,55]$ reported LODs of $7.7-20 \mu \mathrm{g} \mathrm{L}^{-1} \mathrm{~Pb}^{2+}$, with an analysis time of 5-15 min. With the resin, AV-17 using PAR [17,19], LODs were reported to be $10-20 \mu \mathrm{g} \mathrm{L}^{-1}$ $\mathrm{Pb}^{2+}$, with an analysis time of $5 \mathrm{~min}$. The proposed procedure in this work may be not as sensitive as those [9,12-14], but it is still useful for monitoring screening, in accordance with the guideline of $50 \mu \mathrm{g} \mathrm{L}^{-1}$ [1]. In addition, the proposed procedure offers other advantages, namely greater cost effectiveness when considering the sensor material (PUF-PAR), and simple operation with simple apparatus. The use of a smartphone offers the novel detection of lead via 
the developed chemical sensor (monolithic PUF-PAR rod), in association with other benefits, such as providing sampling locations for the possible mapping of the monitoring scheme. In terms of analysis time, the proposed procedure in this work requires a long period in order for the loaded monolithic PUF-PAR rod to be dried; parallel operations could be arranged to compensate for the time.

The proposed procedure indicates that its sensitivity would be useful for the on-site screening of drinking water in Thailand, which should be useful to some organizations such as the Pollution Control Department of Thailand, a rural waterworks authority (such as in Klity village, Kanchanaburi, Thailand), and for rural places without external power and where the budget is limited.

\subsection{Interference Study}

Using PAR as the chelating color agent, some co-existing metal ions in drinking water such as $\mathrm{Ca}^{2+}, \mathrm{Fe}^{3+}, \mathrm{Cu}^{2+}$, and $\mathrm{Zn}^{2+}$ were examined for potential interference. A higher standard deviation than $\pm 15 \%$ of the $\mathrm{G} / \mathrm{B}$ value was taken as interference. In this work, the ratios of $[\mathrm{Ion}] /\left[\mathrm{Pb}^{2+}\right]$ were evaluated, indicating the tolerant limits as 500 for $\mathrm{Ca}^{2+}$; 0.2 for $\mathrm{Fe}^{2+}, \mathrm{Co}^{2+}, \mathrm{Ni}^{2+}$, and $\mathrm{Cu}^{2+}$; and 1 for $\mathrm{Fe}^{3+}, \mathrm{Zn}^{2+}$, and $\mathrm{Cd}^{2+}$. The observed results may possibly be in connection with the potential for complexation formation of the metal ions with PAR, by considering the stability constants [56-59]. In a previous study [60], it was reported that the ratio of $[\mathrm{Ion}] /\left[\mathrm{Pb}^{2+}\right]$ was 500 for $\mathrm{Na}^{+}, \mathrm{K}^{+}, \mathrm{Cl}^{-}, \mathrm{CO}_{3}^{2-}$, and $\mathrm{NO}_{3}^{-}$.

\section{Materials and Methods}

\subsection{Apparatus}

Digital images of $\mathrm{Pb}^{2+}-\mathrm{PAR}$ complexes on monolithic PUF-PAR rods were taken using a smartphone (Lumia 930, Nokia, Tampere, Finland) in manual mode. The smartphone camera settings were as follows: white balance, daylight; ISO, 200; shutter speed, 1:3200; brightness, 0.5 ; and zoom, 20 $\times$. A light-controlled photograph box (UDIOBOX UDIO BIZ $40 \times 40 \times 40 \mathrm{~cm}$, Bangkok, Thailand) was used. ImageJ software (National Institutes of Health, Bethesda, ML, USA) was chosen for processing the images. An inductively coupled plasma emission spectrometer, ICP-OES (Perkin Elmer, Optima 8000, Waltham, MA, USA), was used for method validation. A digital $\mathrm{pH}$ meter (METTLER TOLEDO, Greifensee, Switzerland) was employed for measuring the $\mathrm{pH}$ of solutions.

\subsection{Reagents and Materials}

All chemical reagents used in this work were of analytical grade. Deionized water was used for solution preparation.

A $1000 \mu \mathrm{g} \mathrm{mL}^{-1}$ stock solution of $\mathrm{Pb}^{2+}$ was prepared by dissolving $0.160 \times g$ of $\mathrm{Pb}\left(\mathrm{NO}_{3}\right)_{2}$ (Loba Chemie, Mumbai, India) in $100 \mathrm{~mL}$ of water in a volumetric flask. Working solutions with various concentrations of $\mathrm{Pb}^{2+}$ were prepared daily by diluting with deionized water.

The solution of $0.05 \% w / v$ of 4-(2-pyridylazo) resorcinol (PAR) at $\mathrm{pH} 7$ was prepared by dissolving $0.05 \mathrm{~g}$ of 4-(2-pyridylazo) resorcinol (TCI, Tokyo, Japan) in $1 \mathrm{~mol} \mathrm{~L}^{-1} \mathrm{NaOH}$, adjusting the $\mathrm{pH}$ to 7 with $2 \mathrm{~mol} \mathrm{~L}^{-1}$ of nitric acid, and diluting it to $100 \mathrm{~mL}$ in a volumetric flask with deionized water.

\subsection{Preparation of Monolithic PUF-PAR Rod}

The monolithic PUF rod was synthesized by mixing methylene diphenyl diisocyanate (MDI; IRPC, Rayong, Thailand) with polyol (polyether; IRPC, Rayong, Thailand) at a ratio of 2:1 with a few drops of water and silicone oil in a beaker. Two open-ended glass tubes, each $0.8 \mathrm{~cm}$ i.d. $\times 1.0 \mathrm{~cm}$ o.d. $\times 5.0 \mathrm{~cm}$ in length, were plugged into the mixture. The reaction was allowed to continue for $5 \mathrm{~min}$. The obtained PUF rod was approximately $2 \mathrm{~cm}$ in height. The synthesized PUF rods were then cleaned with water and loaded with $0.05 \% w / v$ PAR ( $\mathrm{pH} 7$ ) for $1 \mathrm{~h}$. Finally, the loaded foam was rinsed with water to remove 
the excess PAR before drying at room temperature overnight. The monolithic PUF-PAR rods could be used for at least a week.

\subsection{General Procedure for Lead Determination Using Monolithic PUF-PAR Rod}

The monolithic PUF-PAR rod was loaded by an analyte solution with a desired volume. Image processing was performed via ImageJ to obtain a color value. A single standard calibration was plotted in terms of $\mu \mathrm{g} \mathrm{Pb}^{2+} \mathrm{vs}$. the signal of an image property. The amount of $\mathrm{Pb}^{2+}$ in the sample was then calculated.

\section{Conclusions}

A novel method for monitoring lead contents in water, by using smartphone detection and employing PUF immobilized with a PAR monolithic rod as a ready-to-use simple chemical sensor was proposed, by following the IUPAC definition of a chemical sensor. The PUF could be easily synthesized in simple lab conditions and lead to the simple fabrication of a monolithic PUF rod. With a PAR solution being loaded to the rod, the obtained monolithic PUF-PAR rod, serving as a ready-to-use chemical sensor, has a shelflife of at least one week. The monolithic characteristics offer advantages over the previous conventional forms of PUF, including the smooth flow of the loading of an analyte solution (standard/sample), and the fact that no sample pretreatment is required. Lead content in a water sample can be assayed via the single standard calibration approach, with the concept of a one-shot image, in one single operation with nine rods: six rods for standards of different amounts of lead loaded on the monolithic PUF-PAR rods, and three rods of a sample for triplicate analysis. By this method, the triplicate results of the final concentration of lead in the sample can be obtained even when using different loading volumes. This offers a method through which to verify the obtained results. The additional advantage is that if the operation results in the loaded amounts of $\mathrm{Pb}^{2+}$ producing a color, with PAR being outside the calibration graph, which is a plot of $\mu \mathrm{g} \mathrm{Pb}^{2+}$ loaded vs. the G/B value, then a new operation can be re-run immediately so that an appropriate result can be obtained. The developed method offers various benefits, even with the simple apparatus used. It is useful for screening following Thailand's guidelines for health effects, which list a maximum allowance of $50 \mu \mathrm{g} \mathrm{L}^{-1}$ for lead in drinking water. The smartphone serves not only as a detector, but also as the provider of the sampling location. This leads to the ability to map lead in water as part of a cost-effective schedule.

Supplementary Materials: Figure S1: Lead assay with smartphone detection: $A=$ ready-to-use sensor, $\mathrm{B}=$ detection (loading and photographing) 18 and $\mathrm{C}=$ evaluation.

Author Contributions: Conceptualization, M.V. and K.G.; Experimental work, P.I.N.A.; Data analysis and evaluation data, M.V., K.G., P.I.N.A., C.Y. and K.K. (Kullapon Kesonkan); Writing—original draft preparation, P.I.N.A., M.V. and K.G.; Writing—review and editing, M.V., K.G., P.I.N.A., K.K. (Kanokwan Kiwfo), C.Y. and K.K. (Kullapon Kesonkan); Supervision, M.V., K.G., N.T. and H.M.; Funding acquisition, M.V. and K.G. All authors have read and agreed to the published version of the manuscript.

Funding: This work was supported by the Science Achievement Scholarship of Thailand (SAST), the TRF Distinguished Research Professor Award Grant (DPG6080002 to Kate Grudpan) and Center of Excellence for Innovation in Analytical Science and Technology, Chiang Mai University.

Institutional Review Board Statement: Not applicable.

Informed Consent Statement: Not applicable.

Data Availability Statement: All of the data are reported in this manuscript and supplementary material.

Acknowledgments: Department of Chemistry, Faculty of Science, King Mongkut's University of Technology Thonburi, Science Achievement Scholarship of Thailand (SAST), Petchra Pra Jom Klao Research Scholarship from King Mongkut's University of Technology Thonburi, and TRF Distinguished Research Professor Award Grant (DPG6080002) and Chiang Mai University are acknowledged. We are grateful to Siripat Suteerapataranon for the useful discussions. 
Conflicts of Interest: The authors declare no conflict of interest.

\section{References}

1. Pollution Control Department of Thailand. Available online: http://pcd.go.th/info_serv/reg_std_water01.html (accessed on 15 August 2021).

2. Gottler, R.A. Part 3000 metals. In Standard Methods for the Examination of Water and Wastewater, 23rd ed.; American Public Health Association: Washington, DC, USA, 2017; pp. 3-15-3-83.

3. Asgharinezhad, A.A.; Ebrahimzadeh, H.; Rezvani, M.; Shekari, N.; Loni, M.A. Novel 4-(2-pyridylazo) resorcinol functionalised magnetic nanosorbent for selective extraction of $\mathrm{Cu}(\mathrm{II})$ and $\mathrm{Pb}(\mathrm{II})$ ions from food and water samples. Food Addit. Contam. 2014, 31, 1196-1204. [CrossRef]

4. Cai, Y.; Ren, B.; Peng, C.; Zhang, C.; Wei, X. Highly sensitive and selective fluorescence turn-on detection of Pb (II) based on $\mathrm{Fe}_{3} \mathrm{O}_{4} @ \mathrm{Au}$-FITC nanocomposite. Molecules 2021, 26, 3180. [CrossRef]

5. Guo, Y.; Liu, C.; Ye, R.; Duan, Q. Advances on water quality detection by UV-vis spectroscopy. Appl. Sci. 2020, 10, 1-18. [CrossRef]

6. Asghari, A.; Mohammadi, B. Nano-alumina coated with sodium dodecyl sulfate and modified with 4-(2-Pyridylazo) resorcinol for extraction of heavy metals in different matrixes. J. Ind. Eng. Chem. 2014, 20, 824-829. [CrossRef]

7. Lu, W.; Lin, C.; Yang, J.; Wang, X.; Yao, B.; Wang, M. A DNAzyme assay coupled with effective magnetic separation and rolling circle amplification for detection of lead cations with a smartphone camera. Anal. Bioanal. Chem. 2019, 411, 5383-5391. [CrossRef]

8. Wang, H.; Yang, L.; Chu, S.; Liu, B.; Zhang, Q.; Zou, L.; Yu, S.; Jiang, C. Semiquantitative Visual Detection of Lead Ions with a Smartphone via a Colorimetric Paper-Based Analytical Device. Anal. Chem. 2019, 91, 9292-9299. [CrossRef] [PubMed]

9. Zhang, W.; Liu, C.; Liu, F.; Zou, X.; Xu, Y.; Xu, X. A smart-phone-based electrochemical platform with programmable solidstate-microwave flow digestion for determination of heavy metals in liquid food. Food Chem. 2020, 303, 125378. [CrossRef] [PubMed]

10. Sahu, B.; Kurrey, R.; Deb, M.K.; Shrivas, K.; Karbhal, I.; Khalkho, B.R. A simple and cost-effective paper-based and colorimetric dual-mode detection of arsenic(III) and lead(II) based on glucose-functionalized gold nanoparticles. RSC Adv. 2021, 11, 2076920780. [CrossRef]

11. Satarpai, T.; Shiowatana, J.; Siripinyanond, A. Paper-based analytical device for sampling, on-site preconcentration and detection of ppb lead in water. Talanta 2016, 154, 504-510. [CrossRef]

12. Kang, W.; Pei, X.; Rusinek, C.A.; Bange, A.; Haynes, E.N.; Heineman, W.R.; Papautsky, I. Determination of lead with a copperbased electrochemical sensor. Anal. Chem. 2017, 89, 3345-3352. [CrossRef]

13. Alam, A.U.; Howlader, M.M.R.; Hu, N.-X.; Deen, M.J. Electrochemical sensing of lead in drinking water using $\beta$-cyclodextrinmodified MWCNTs. Sens. Actuators B 2019, 296, 126632. [CrossRef]

14. Frutos-Puerto, S.; Miró, C.; Pinilla-Gil, E. Nafion-protected sputtered-bismuth screen-printed electrode for on-site voltammetric measurements of $\mathrm{Cd}(\mathrm{II})$ and $\mathrm{Pb}(\mathrm{II})$ in natural water samples. Sensors 2019, 19, 279. [CrossRef]

15. Dagnal, R.M.; West, T.S.; Young, P. Determination of Lead with 4-(2-pyridylazo)-resorcinol-I: Spectrophotometry and solvent extraction. Talanta 1965, 12, 583-588. [CrossRef]

16. Rahman, I.; Furusho, Y.; Begum, Z.; Sato, R.; Okumura, H.; Honda, H.; Hasegawa, H. Determination of lead in solution by solid phase extraction, elution, and spectrophotometric detection using 4-(2-pyridylazo)-resorcinol. Cent. Eur. J. Chem. 2013, 11, 672-678. [CrossRef]

17. Shvoeva, O.P.; Dedkova, V.P.; Savvin, S.B. Determination of lead with 4-(2-pyridylazo)resorcinol after the sorption of lead as its thiosulfate complex on a fibrous sorbent filled with AV-17. J. Anal. Chem. 2001, 56, 1080-1083. [CrossRef]

18. Dedkova, V.P.; Shvoeva, O.P.; Savvin, S.B. Effect of anions on the development of color reactions of cadmium, lead, and mercury with dithizone and 4-(2-pyridylazo)resorcinol on a fibrous material filled with the anion exchanger AV-17. J. Anal. Chem. 2003, 58, 230-235. [CrossRef]

19. Dedkova, V.; Shvoeva, O.; Savvin, S. Test method for the separate determination of mercury(II), cadmium, and lead in one sample on the fibrous sorbent PANV-AV-17. J. Anal. Chem. 2006, 61, 813-818. [CrossRef]

20. Santos, W.L.D.; Santos, C.M.M.D.; Costa, J.L.O.; Andrade, H.M.C.; Ferreira, S.L.C. Multivariate optimization and validation studies in on-line pre-concentration system for lead determination in drinking water and saline waste from oil refinery. Microchem. J. 2004, 77, 123-129. [CrossRef]

21. Tokalioglu, S.; Kartal, S. Preconcentration of iron(III), lead(II), cobalt(II) and chromium(III) on amberlite XAD-1180 resin loaded with 4-(2-pyridylazo)-resorcinol (PAR) and their determination by FAAS. Bull. Korean Chem. Soc. 2006, $27,1293-1296$.

22. Klamtet, J.; Sanguthai, S.; Sriprang, S. Determination of lead in aqueous samples using a flow injection analysis system with on-line preconcentration and spectrophotometric detection. NU. Int. J. Sci. 2007, 4, 122-131.

23. Yanovskaya, E.S.; Nazarenko, E.V. Formation of the mixed-ligand complexes of lead(II), cadmium(II), and zinc(II) sorbed on the surface of silicas with chemically immobilized N-propyl-N'-allylthiourea and mercaptopropyl groups. Russ. J. Inorg. Chem. 2007, 52, 505-509. [CrossRef]

24. Bojdi, M.K.; Mashhadizadeh, M.H.; Behbahani, M.; Farahani, A.; Davarani, S. Synthesis, characterization and application of novel lead imprinted polymer nanoparticles as a high selective electrochemical sensor for ultra-trace determination of lead ions in complex matrixes. Electrochim. Acta 2014, 136, 59-65. [CrossRef] 
25. Mattio, E.; Robert-Peillard, F.; Branger, C.; Puzio, K.; Margaillan, A.; Brach-Papa, C.; Knoery, J.; Boudenne, J.L.; Coulomb, B. 3D-printed flow system for determination of lead in natural waters. Talanta 2017, 168, 298-302. [CrossRef] [PubMed]

26. Xing, G.; Sardar, M.R.; Lin, B.; Lin, J.-M. Analysis of trace metals in water samples using NOBIAS chelate resins by HPLC and ICP-MS. Talanta 2019, 204, 50-56. [CrossRef]

27. Duangthong, S.; Kamhang, R.; Wararatananuruk, P.; Chooto, P.; Tapachai, W.A. Simple on-line preconcentration spectrophotometry for detecting lead contamination from drinking water coolers and glazed bowl samples. Anal. Bioanal. Chem. Res. 2020, 7 , 473-482.

28. Rodríguez-Maese, R.; Ferrer, L.; Cerdà, V.; Leal, L.O. Fully automatic system for lead monitoring in water. Microchem. J. 2020, 154, 104550. [CrossRef]

29. Smirnova, S.V.; Ilin, D.V.; Pletnev, I.V. Extraction and ICP-OES determination of heavy metals using tetrabutylammonium bromide aqueous biphasic system and oleophilic collector. Talanta 2021, 221, 121485. [CrossRef] [PubMed]

30. Lemos, V.; Ferreira, S. On-line preconcentration system for lead determination in seafood samples by flame atomic absorption spectrometry using polyurethane foam loaded with 2-(2-benzothiazolylazo)-2-p-cresol. Anal. Chim. Acta 2001, 441, 281-289. [CrossRef]

31. Gama, E.M.; Lima, A.D.S.; Lemos, V.A. Preconcentration system for cadmium and lead determination in environmental samples using polyurethane foam/Me-BTANC. J. Hazard. Mater. 2006, 136, 757-762. [CrossRef]

32. Anthemidis, A.N.; Zachariadis, G.A.; Stratis, J.A. On-line preconcentration and determination of copper, lead and chromium(VI) using unloaded polyurethane foam packed column by flame atomic absorption spectrometry in natural waters and biological samples. Talanta 2002, 58, 831-840. [CrossRef]

33. Azeem, S.A.; Arafa, W.A.A.; El-shahat, M. Synthesis and application of alizarin complexone functionalized polyurethane foam: Preconcentration/separation of metal ions from tap water and human urine. J. Hazard. Mater. 2010, 182, 286-294. [CrossRef]

34. Tarley, C.R.T.; Arruda, M.A.Z. OnLine coupling of a flow injection system to TS-FF-AAS for preconcentration and determination of lead in water and vegetables. Anal. Lett. 2005, 38, 1427-1443. [CrossRef]

35. Burham, N. Separation and preconcentration system for lead and cadmium determination in natural samples using 2-aminoacetylthiophenol modified polyurethane foam. Desalination 2009, 249, 1199-1205. [CrossRef]

36. Lemos, V.A.; Lima, A.D.S.; Santos, J.S.; Castro, J.T.; Ferreira, S.L.C. Determination of lead in water samples after its separation and preconcentration by 4,5-dihydroxy-1,3-benzenedisulfonic acid functionalised polyurethane foam. Int. J. Environ. Anal. Chem. 2012, 92, 1121-1134. [CrossRef]

37. Moawed, E.; Elhagrasy, M.; Kamal, M. Detection and removing of lead from wastewater using chemical treatment of polyurethane foam waste: Batch and column experiments. Desalin. Water Treat. 2019, 159, 338-345. [CrossRef]

38. Santos, W.N.L.D.; Santos, J.V.S.; Silva, L.O.B.; Araújo, A.S.; Lemos, V.A.; Miró, M.; Ferreira, S.L.C. On-line simultaneous preconcentration procedure for the determination of cadmium and lead in drinking water employing sequential multi-element flame atomic absorption spectrometry. Int. J. Environ. Anal. Chem. 2011, 91, 1425-1435. [CrossRef]

39. Burham, N.; Abdel-Azeem, S.M.; El-Shahat, F. Determination of lead and cadmium in tap water and apple leaves after preconcentration on a new acetylacetone bonded polyurethane foam sorbent. Int. J. Environ. Anal. Chem. 2008, 88, 775-789. [CrossRef]

40. Sant'Ana, O.D.; Jesuino, L.S.; Cassella, R.J.; Carvalho, M.S.; Santelli, R.E. Determination of lead by electrothermal atomic absorption spectrometry employing a novel sampling strategy of polyurethane foam impregnated with thiazolylazo-p-cresol (TAC). J. Braz. Chem. Soc. 2004, 15, 96-102. [CrossRef]

41. Ferreira, S.; Santos, W.; Bezerra, M.; Lemos, V.A.; Bosque-Sendra, J. Use of factorial design and doehlert matrix for multivariate optimisation of an on-line preconcentration system for lead determination by flame atomic absorption spectrometry. Anal. Bioanal. Chem. 2003, 375, 443-449. [CrossRef] [PubMed]

42. Lemos, V.A.; Guardia, M.D.L.; Ferreira, S.L.C. An on-line system for preconcentration and determination of lead in wine samples by FAAS. Talanta 2002, 58, 475-480. [CrossRef]

43. Quináia, S.P.; Silva, J.B.B.D.; Rollemberg, M.D.C.E.; Curtius, A.J. Preconcentration of lead complexed with O,O-diethyldithiophosphate by column solid-phase extraction using different sorbents in a flow injection system coupled to a flame atomic absorption spectrometer. Talanta 2001, 54, 687-696. [CrossRef]

44. Silva, J.B.D.; Quináia, S.P.; Rollemberg, M.C. On-line preconcentration with different solid adsorbents for lead determination. Fresenius J. Anal. Chem. 2001, 369, 657-660. [CrossRef] [PubMed]

45. Zhang, Z.; Zhu, L.; Zhang, Z.; Sun, L.; Shi, Y.; Xie, L.; Xu, D.; Jin, J.; Xue, Z.; Ma, X. Synthesis of polyethyleneimine modified polyurethane foam for removal of $\mathrm{Pb}(\mathrm{II})$ ion from aqueous solution. Desalin. Water Treat. 2019, 160, 288-296. [CrossRef]

46. Muginova, S.V.; Veselova, I.A.; Parova, L.M.; Shekhovtsova, T.N. Enzymatic determination of cadmium, zinc, and lead in plant materials. J. Anal. Chem. 2008, 63, 1005-1014. [CrossRef]

47. Burham, N.; Abdel-Azeem, S.M.; El-Shahat, M.F. Separation and determination of trace amounts of zinc, lead, cadmium and mercury in tap and Qaroun lake water using polyurethane foam functionalized with 4-hydroxytoluene and 4-hydroxyacetophenone. Anal. Chim. Acta 2006, 579, 193-201. [CrossRef] [PubMed]

48. Yeerum, C.; Wongwilai, W.; Grudpan, K.; Vongboot, M. Green assay of anionic surfactant via ion-association with methylene blue sorbed on polyurethane foam monolithic rod and using a smartphone. Talanta 2018, 190, 85-88. [CrossRef] 
49. Ayutthaya, P.I.N.; Yeerum, C.; Kesonkan, K.; Kiwfo, K.; Grudpan, K.; Teshima, N.; Murakami, H.; Vongboot, M. Determination of lead employing simple flow injection AAS with monolithic alginate-polyurethane composite packed in-valve column. Molecules 2021, 26, 4397. [CrossRef]

50. Hulanicki, A.; Glab, S.; Ingman, F. Chemical sensors: Definitions and classification. Pure Appl. Chem. 1991, 63, 1247-1250. [CrossRef]

51. Marchisio, P.; Sales, A.; Cerutti, S.; Marchevsky, E.; Martinez, L. On-line preconcentration/determination of lead in Ilex paraguariensis samples (Mate tea) using polyurethane foam as filter and USN-ICP-OES. J. Hazard. Mater. 2005, 124, 113-118. [CrossRef]

52. Bowen, H.J.M. Absorption by polyurethane foams; new method of separation. J. Chem. Soc. A 1970, 1082-1085. [CrossRef]

53. Kocyła, A.; Pomorski, A.; Krężel, A. Molar absorption coefficients and stability constants of metal complexes of 4-(2pyridylazo)resorcinol (PAR): Revisiting common chelating probe for the study of metalloproteins. J. Inorg. Biochem. 2015, 152, 82-92. [CrossRef]

54. Zaini, M.A.A.; Amano, Y.; Machid, M. Enhanced lead(II) binding properties of heat-treated cattle-manure-compost-activated carbon. Desalin. Water Treat. 2014, 52, 6420-6429. [CrossRef]

55. Shrivas, K.; Sahu, B.; Deb, M.K.; Thakur, S.S.; Sahu, S.; Kurrey, R.; Kant, T.; Patle, T.K.; Jangde, R. Colorimetric and paper-based detection of lead using PVA capped silver nanoparticles: Experimental and theoretical approach. Microchem. J. 2019, 150, 104156. [CrossRef]

56. Nonova, D.; Evtimova, B. Complex formation of nickel(II) and cobalt(II) with 4-(2-pyridylazo)-resorcinol. Anal. Chim. Acta 1972, 62, 456-461. [CrossRef]

57. Nonova, D.; Evtimova, B. Complexing of Iron(II) and Iron (III) by 4-(2-pyridylazo) resorcinol. J. Inorg. Nucl. Chem. 1973, 35, 3581-3586. [CrossRef]

58. Smith, R.M.; Martell, A.E. Critical Stability Constants Volume 2; Plenum Publishing Corporation: New York, NY, USA, 1975; pp. 178-179.

59. Gomez, E.; Estela, J.M.; Cerda, V. Simultaneous spectrophotometric determination of calcium and magnesium in water. Anal. Chim. Acta 1991, 249, 513-518. [CrossRef]

60. Saeidi, M.; Shamsipur, M. Complex formation between alkaline earth cations and 4-(2-pyridylazo)resorcinol in ethanol water mixtures. J. Coord. Chem. 1990, 22, 131-137. [CrossRef] 